\title{
Wildness and colonialism in "The Story of Two Dogs" by Doris Lessing
}

\section{Pat Louw}

Pat Louw is a Research Associate of the University of Zululand, English Department.

Email: patzini@gmail.com

\section{Wildness and colonialism in "The Story of Two Dogs" by Doris Lessing}

Dogs play an important role in colonial society, especially in Africa. While the project of colonisation involves settling in a new country and confronting wild animals, the dog is one animal on which the settler can rely as an ally, protector and companion. Settler dogs whose breeds stem from Britain are in a sense the animal counterpart of the human settler. When these animals desert their owners either by cross-breeding with indigenous dogs or reverting to the wild, it can seem like a betrayal of their settler owners and of the colonial project. Doris Lessing explores this dilemma in "The Story of Two Dogs" which is a semiautobiographical story of her family and their dogs. She grew up in the 1930s on a farm in colonial Rhodesia. Lessing creates an ironical narrative voice that undermines colonial discourse and exposes racial and class prejudice among the settler community. Through the lens of the dogs she also draws attention to gender conflict and the subjugation of women in matters of dog training and hunting. In addition, conflict between adults and children is brought out which points to possibilities of a more open approach to the question of dog breeding, training and ownership. She also raises questions about the ultimate nature of the dog and its status as a domesticated animal. Keywords: colonialism; dogs; Doris Lessing; wildness.

Susan McHugh, in her book, Dog, writes: "The difficulty of representing dogs-let alone accounting for how they have become a central part of the human experience-reflects the ongoing struggle of defining what a dog is" (7). In the story under discussion in this paper, Doris Lessing chooses to represent the dog in a way that calls into question some of the accepted norms of dog ownership. It is a story that raises questions about the interaction between human beings and dogs, asking questions involving domestication and training and the essential nature of the dog. All these questions are raised within the context of colonialism. This study will therefore attempt to encompass the concept of wildness with regard to 
domestic animals, and in particular, dogs, as seen in the context of colonialism as it is represented in this story. It will explore issues of race, gender and generational conflict as focussed through dogs. I will be referring to colonial discourse in my analysis of Lessing's African writings and her position in relation to colonialism. Colonial discourse theorist Sara Mills points out a way in which writings during the colonial period may be evaluated:

Whilst it is clear that individuals cannot be held responsible for the larger scale organisation of imperialism, it is also clear that individuals differed in the degree to which they championed, acquiesced or challenged imperialism. Some presented representations which destabilised British colonial involvement, whilst others affirmed colonial rule in their writings. (9)

I argue that Doris Lessing "destabilised" and undermined British colonial involvement in her African Stories, partly through her construction of wildness. Her stories are published in two volumes: This was the Old Chief's Country (Volume One) and The Sun Between Their Feet (Volume Two). The story under consideration is in Volume Two.

"Wildness" has ambivalent connotations in colonial society. It is a "cultural construct, formed according to people's perceptions of their environment, which are in turn dependent on their social, political, economic and cultural background" (Louw 2). One of the generally-accepted metanarratives of the colonisation of Africa is that the settlers came to bring 'civilisation' and hence to tame the wildness of the landscape, the people and the animals. Colonists are therefore expected to have an adversarial relationship to wildness. Eva Hunter writes: "the notion that the land was empty, and even when not entirely empty in need of 'taming', buttressed the self-righteousness of the white colonisers of southern Africa" (35).

Contrasted with the idea of taming the wild land is Gary Snyder's concept of wildness. He writes: "The word wild is like a gray fox trotting off through the forest, ducking behind bushes, going in and out of sight" (9). He seems to be suggesting that the meaning of wildness cannot be tied down by one view. While he notes that most definitions of 'wild' are negative (undomesticated; not tame; not cultivated), he prefers to define this term more positively: "Of land-a place where the original and potential vegetation and fauna are intact and in full interaction and the landforms are entirely the result of nonhuman forces" (10). Snyder's positive view of wildness forms a counterpoint to the generally negative view of the settler culture towards wildness; a view which Lessing critiques in her story.

Connected with the concept of 'wildness' is the so-called Myth of the Empty Land which is part of British Colonial discourse, according to Chennells (4). Lessing, however, was very much aware of the fact that Africa was not empty, but peopled by previous inhabitants, as is shown by the title of her first volume of African Stories: This was the Old Chief's Country. However, Chennells maintains that she subscribes to part of that myth: "Lessing seems, to an extent, to have identified 
Wildness and colonialism in "The Story of Two Dogs" by Doris Lessing

with settlers who saw in the empty land an opportunity for self-realization and for the free development of personality, impossible to achieve in England or even in Rhodesia's towns" (4). Indeed, Lessing seems to recognise that there is something in the wild environment that can be both frightening and attractive for the settler. Rider-Haggard is an example of a colonial writer who responds favourably to the wildness of Africa: "It was the wildness of African terrain as opposed to the domesticity of English farmland that captured him" (Stiebel 92). Although many settlers in Lessing's stories share the imperative of "taming the wilderness", there are some who value wildness, especially with regard to animals. There is thus a tension between people who are antagonistic towards wildness and those who are open to wildness in some of its manifestations.

Doris Lessing's African Stories give a complex picture of the early settlers in colonial Southern Rhodesia as it was in the 1920s and 1930s. This is apparently a neglected period in Rhodesian/Zimbabwean history, according to Sabelo J. Ndlovu-Gatsheni: "With the exception of Ranger's book, The African Voice in Rhodesia, little scholarly writing has dealt with this crucial phase of early colonial history" (174). Although Lessing's stories are not strictly historical accounts, they are in some ways more 'true' than a genre like autobiography. In her autobiography, Under My Skin, she makes this point:

When I wrote Martha Quest I was being a novelist and not a chronicler. But if the novel is not the literal truth, then it is true in atmosphere, feeling, more "true" than this record, which is trying to be factual. Martha Quest and my African short stories are a reliable picture of the District in the old days. That is, from a white point of view. (162)

Lessing's last sentence here indicates that she is well aware of her limited perspective in a racially divided country, but she does not seem to see it as a burden, unlike the life narratives of J. M. Coetzee and Alexander Fuller, who do, according to Tony Simoes Da Silva:

Ultimately, life narratives such as Boyhood and Don't Let's go to the Dogs Tonight show how, in the post-colonial moment, of Southern Africa of post-1980 Zimbabwe, and post-1994 in SA stories of self are now constrained by a heightened awareness of privilege - now in effect coded as a burden — of whiteness. (476)

I would argue that Doris Lessing is writing from a postcolonial perspective even though she writes during the colonial era. She does this by undermining colonial discourse and exposing racism and class prejudice, and in this story she does this through the focus on the dogs.

In the African Stories, Lessing blends the genres of autobiography and fiction. Susan Watkins writes: "Her constructive and complex use of autobiographical material also creatively interacts with, indeed generates, her interest in the writer or artist both as figure in and producer of the text" (1). This is often evident in her African stories where the narrator is a young adolescent girl as in "The Story

Tydskrif vir Letterkunde 55.3 (20I8) 
of Two Dogs" in which Lessing's whole family seems to be represented. The dogs are their family dogs, as Lessing explains in her 1973 introduction to the African Stories:

"The Story of Two Dogs" [...] which I think is as good as any I have done. And it is a "true" story: at least, there were two pairs of dogs in my childhood, the first called Lion and Tiger, and the second Jock and Bill. I don't know now which incidents belong to which pair of dogs; but it is true that Bill, or the "stupid" dog, rescued Jock, the "clever" dog, by gnawing through a strand of wire in which he was trapped-thus wearing his teeth down to stubs and shortening his life. (7)

Lessing's father came to Southern Rhodesia (as it was then) after the First World War, and bought a farm in the Banket district, where Lessing spent her early years. This was a time of intense British colonialism in Africa. She exposes the racial prejudice of the day at the outset of this story, in connection with the older dog, Jock: "It had been decided: 'Jock needs a companion, otherwise he'll spend his time with those dirty kaffir dogs in the compound' (Lessing, Sun 189).

While the use of this derogatory language is offensive, it is also ironic as it shows the futility of trying to impose racial prejudices onto dogs, who are unaware of the racial and cultural boundaries set up by their human owners. Clearly humans want to control the social habits and behaviour of their animals-and each other, within the larger paradigm of colonialism.

It may be instructive to compare the narrative voice in this story with that of the narrator in the iconic colonial dog narrative, Jock of the Bushveld. The narrators differ vastly in their circumstances. The narrator in Jock is a young man, travelling around with a group of hunters with no fixed abode. Lessing's narrator is a young girl living on a farm with her family. Hers is a 'farm' narrative whereas his is an adventure or travel narrative. However, both of them have to deal with the race question. Both writers use the word 'kaffir', but in very different ways. Lessing never uses the word to describe people. If she refers to an indigenous inhabitant of the land, she uses the term 'native.' However, she uses the word as an adjective: a kaffir path; a kaffir dog. In this she is reflecting the use of these terms in settler society. The narrator of Jock, however, uses this term to describe people. "Jock disliked kaffirs: so did Jim” (Fitzpatrick 209). This sentence has some humour in it as Jim is black and looks down on other African tribes, but, nevertheless, for a contemporary reader, it is an offensive use of this term and indicates that the writer is a proponent of colonial discourse.

In terms of a spatial analysis of this story, Lessing creates distinct spaces in the narrative-the compound, the farmyard and the wild bush. She uses these spaces to construct complex subjectivities in her stories, especially when these boundaries are crossed. The dogs complicate these human divisions and provide an alternative narrative that undermines the authority of the settler discourse. 
Wildness and colonialism in "The Story of Two Dogs" by Doris Lessing

Another way of undermining the settler discourse is through narrative technique. Lessing uses the young girl as a focaliser and the retrospective "I" narration. This enables the young girl to distance herself from the settler mind-set. For example, the remark, "it had been decided" makes a distinction between the adult world and the child's reporting of this conversation. There is a suggestion that the child might not agree with the parents' view. This potential conflict between the older and younger generation is expanded as the story develops.

The difficulty which the family has in finding a companion dog for Jock is related to the question of breeding. Through controlled breeding of dogs, humans have developed certain qualities in the dogs to suit human needs. Wendy Woodward states: "As domesticated nonhuman animals, dogs are our responsibility entirely. Dogs also, in their breeds, are middle class creations" (91). Considering that dogs were domesticated before the Agrarian Revolution, this statement needs to be modified to relate directly to the colonial situation. In South Africa, it appears from interviews with black farmers in the Transkei that there was dogbreeding among black farmers early in the twentieth century: "There were people who used to breed long dogs which are good at catching wild animals. Those dogs were called amangesi" (Tropp 462). Indeed, the question of breeding in this story is a marker of the colonial mentality and is of course closely related to race. In Rhodesian settler society, good dogs are British dogs that have been imported to Africa: dogs that have been bred to perform certain functions, such as herding or hunting. The settlers do not seem to notice that the African dogs are good hunters too. This is illustrated when one of the workers on the farm offers a puppy to the household, but is rejected:

Jacob, our builder, heard we wanted another dog, and came up with a lively puppy on the end of a bit of rope. But we tactfully refused. The thin flea-bitten little object was not good enough for Jock, my mother said; though we children were only too ready to take it in. (Lessing, Sun 189)

Here conflict between the children and the parents begins to unfold. This is a familiar pattern in many of Lessing's African stories. The adults of her parent's age, being first-generation settlers, bring many of their British notions with them with regard to dogs. The children are less hampered by these prejudices and are able to respond to the vital essence of the animal instead of the prescriptive formula of what a good dog should be. Within colonial discourse, Lessing begins to build a counter-discourse.

To some extent, Lessing treats the obsession with breeding humorously. She shows that the reason why breeding is so important for the settler is that they construct the dog's identity in terms of their own. For example, in describing the puppy's mother, we read: "She was no pure-bred herself, though of course her owners thought she was, or ought to be, being their dog" (195). The identity of 
the dog is eclipsed by the owners' sense of self: they construct the dog's identity in terms of their own.

Lessing also shows that there is a dark side to the breeding issue. It can have fatal consequences for the dogs. A dog that has been sullied in some way either by connection with a compound dog or by contact with a dog that has gone wild, is said to have "bad blood". The puppies that are the issue of such a union are usually drowned.

Although questions of race are at the forefront of the story initially, there are other aspects of human society that are illuminated by a focus on the dogs. Both of the parents communicate indirectly with their children and each other through the dog, Jock. They acquire this dog at the time when their son goes to boarding school. It is meant to be the boy's dog, but the narrator explains: "In fact my brother's dog was his substitute" (89). All the mother's pent-up maternal energies are bestowed on the dog, insisting that he is "delicate" and needs to be protected and nursed. Not only is the dog a substitute for the absent son; he is also a substitute for other members of the family who refuse to allow her to treat them in this way. The narrator feels that

$[\ldots]$ there was something in the whole business that was a reproach to us $[\ldots]$ if we had allowed ourselves to be delicate, and good, or even gentlemen and ladies, there would have been no need for Jock to sit between my mother's knees, his loyal noble head on her lap, while she caressed and yearned and suffered. (190)

The dog here is the medium through which this mother tries to manipulate her family members to feel guilty for their lack of response to her needs. The father, too, communicates indirectly with both his wife and his son when he speaks about Jock:

It was my father who decided there must be another dog, and for the expressed reason that otherwise Jock would be turned into a "sissy". (At this word, reminder of a hundred earlier battles, my brother flushed, looked sulky, and went right out of the room). (191)

The dog therefore plays an important role in the family dynamics. One could also say that the dog is a marker of the character of the mother in that it reveals her desperate need to nurse and pet someone and also her subtle way of sending indirect complaints and reproaches to her family. It also suggests that she is trying to counter the destructive outcomes of the paradigm she is caught in as a woman in colonial society.

The dogs in this story become the medium through which gender conflict is revealed. The mother's emotional reaction to Jock's visiting the compound seems to indicate that more than the dog's behaviour is at stake. She interprets Jock's natural, animal instincts as not only disobedience but betrayal:

"Oh you bad dog, Jock," she said sorrowfully, "playing with those nasty dirty dogs, how could you, Jock!” And he would playfully, but in an agony of remorse, snap 
Wildness and colonialism in "The Story of Two Dogs" by Doris Lessing

and lick at her face, while she bent the whole force of her inevitably betrayed self over him, crooning: "How could you, oh how could you, Jock?" (191)

Here the animal seems to be the vehicle, carrying this woman's anger and resentment against someone, unspecified but possibly her husband and possibly settler men in general who are often seen to be betraying their settler wives-never more so than with black women. Here I can refer to another story in The Sun Between Their Feet, "Traitors", which has this theme.

There are further aspects to the gender conflict in the story, with regard to the new puppy. The man's authority is final when it comes to the decision of whether or not to take the puppy. The mother is opposed to it: "you saw how he reacted to the moon, we'll never train him!" (193) But the father imposes his authority, contradicting his wife, who "lowered her eyes forlornly and sat silent" (193). The puppy is the focal point around which the domestic power struggle revolves.

Lessing develops a nuanced sense of settler society as the story develops. It is as if people are set apart through their different attitudes towards the dog. The narrator separates herself from the adults here: "I left the four people to talk about their differences through a small puppy, and went to worship the animal" (194). She alone is able to respond directly to the physicality of the puppy: his glistening brindled coat and pink tongue (194) without any prejudice or hidden interpersonal conflicts colouring her spontaneous pleasure in him. For her he is constructed as an "embodied canine presence" (Woodward 100). She is able to enjoy him with her senses, untroubled by the cerebral and emotional concerns of the adults. Through the representation of the dog, Lessing is separating the generations and showing more openness towards the animal and to nature in general in the young girl.

Training is a practice that is at the centre of the domestication of the dog. Donna Haraway, in Where Species Meet, states that "Many critical thinkers who are concerned with the subjugation of animals to the purposes of people regard the domestication of other sentient organisms as an ancient historical disaster that has only grown worse with time" (206). However, she goes on to suggest that "there are other ways to think about domestication that are both more historically accurate and also more powerful for addressing past and present brutalities and for nurturing better ways to live in multispecies sociality" (207). The example she gives is Agility Training, a competitive sport that people and dogs enter into together. They seem to be equal partners and they learn from one another, so both dog and person have agency. This way of regarding the dog from a human's perspective is similar to Patrick Murphy's concept of "Anotherness" which he uses to critique the concept of the "Other":

The concept of the "Other" has proven to be a valuable tool in psychoanalytic and feminist literary theory and criticism. It has been interpreted in various ways to provide stunning critiques of patriarchy, colonialism, capitalism, metaphysical

Tydskrif vir Letterkunde 55.3 (2018) 
linguistics and Freudianism [...] Ecology and ecocriticism indicate that it is time to move towards a relational model of "anotherness" and the conceptualization of difference in terms of "I" and "another", "one" and "another", and "I-as-another". (40)

In Lessing's story, it seems as though the traditional, historical attitude towards training is attempted, but fails, for reasons to be discussed, and an alternative is followed which in similar to the "anotherness" model, but differs somewhat from Haraway's example as it becomes animal-centred rather than a combination of animal and human. As the narrator explains, the accepted rule in settler society is that "dogs must be trained by their masters, they must owe allegiance to one person" (Lessing, Sun 198). With regard to Bill, the girl says: "I was his master, in theory. In practice, Jock was. Was I to take over from Jock? But even to state it is to expose its absurdity: I adored the graceless puppy, and why did I need a well-trained dog? Trained for what?" (198). She doesn't see the point of teaching a dog to go to heel or fetch a ball. This raises an interesting point about intersubjectivity. In the narrator's view, the young dog, Bill, relates mainly to the older dog, Jock. She thus sees the possibility of the dog having an animal master rather than a human one. However, this is contrary to colonial discourse, according to which, training dogs was essentially a male occupation (an attitude probably much older than colonial discourse and true also for African societies). She writes ironically about her brother taking his new rifle and going to hunt with the dogs as the "time-honoured unit" (201). She tags along although she has "no useful part to play in the serious masculine business, but necessary to provide admiration" (201). Lessing's ironical tone here underlines the patriarchal aspect of colonialism, as it relates to the dog.

The training of these two dogs is unsuccessful. The younger dog is unwilling to listen to her brother and this distracts the older dog. This again is partly due to family dynamics and in particular the Mother's attitude. She personifies the dogs and treats them differently, according to their behaviour, favouring the "good dog", Jock. It seems that the children can't bear to reinforce this pattern, so they abandon the training altogether. "My brother and I watched our mother petting Jock and scolding Bill and came to an unspoken agreement. We set off for the Great Vlei but once there we loafed up and down the water-holes, while the dogs did as they liked, learning the joys of freedom" (204).

The girl's attitude is different to Haraway's Agility Training in which they both compete, learning skills and also learning from each other in close companionship. The girl in Lessing's story basically cedes companionship to the dogs. Their companionship with each other takes precedence over her bond with her dog. Although she and her brother take the dogs with them on their hunting trips, they do not rely on the dogs. It is as if they are loosely connected in a common pursuit and later the dogs go off on their own, independently. 
Wildness and colonialism in "The Story of Two Dogs" by Doris Lessing

With the failure of training, we return to the question of wildness. What is shown about different representatives of settler society through their response to wildness in their dogs? As always, the narrator provides an ironical distance from the mother. At one point in the story, the mother tries to get the dogs to be quiet during the night as they are very responsive to movements and sounds from outside the house. They are turned out onto the veranda, "With many hopeful injunctions from my mother that they were to be 'good dogs': which meant that they should ignore their real natures and sleep from sundown to sun-up" (200). The dry comment by the adolescent narrator elicits questions about what their real nature is. How much of their wildness has been trained out of them, and how much still remains, trapped in their beings, only allowed to show itself in a few instances?

The dogs in this story are caught between wildness and domesticity. Because of the rural setting and the proximity of the wild bush, there is always a space where the dogs can live independently of humans. Jock and Bill gradually spend more and more time in the bush. A process of de-domestication takes place. However, it is a gradual process and in Jock's case it is never completed. The dogs go on their hunting adventures in the bush while the children wait for them and then go home, but after some weeks the dogs go off on their own hunting trips. At first they stay away for a whole night and later a few days and then a week and then basically they come back occasionally to drink water and sleep. The interesting thing is that they continue to regard the farm as their home. One is reminded that the meaning of "domestication" is not only being tamed but is also connected with home and belonging. Although Jock and Bill were considered to have "gone wild", their wild instincts did not prevent them from returning to the farm when they were in need.

Lessing's story can also be read on a metaphorical level where the lives of the dogs parallel the lives of humans who are caught in an oppressive paradigm which denies their "wild" nature. There is a parallel in Lessing's stories between dogs who are considered to have "gone wild" and settlers who have "gone native". This is expressed in another of Lessing's stories in the same volume, "The Story of the Non-Marrying Man" (32-48). The main character, Johnny Blakeworthy, is an Englishman who can't seem to "settle" in the colonial society. He marries a settler woman and stays with her for a while but gets smothered by the materialism and stuffiness of this lifestyle. He then goes to the bush and walks around free, living under the stars and carrying a sack of mielie meal to live off. This pattern is repeated several times as he returns to domesticity and marries a different woman, but the call of the open spaces make him leave that woman as well. In the end he gives up settler life and gets permission from a local chief to live in a hut with a black woman, with whom he lives "in kindness" (48). This behaviour is usually referred to by the settlers as "degeneration". According to Dale Kennedy:

Tydskrif vir Letterkunde 55.3 (2018) 
The symptoms of degeneration ranged from a relatively mild "mental inertia", through a more serious alcoholic profligacy, to the terminal depravity of "going native". This final stage was typified by adopting African dress, housing, customs, and especially by taking an African wife-becoming, in effect, a white African in European eyes. (173)

"Gone Native" for people and "gone wild" for domestic animals have similar connotations. Both involve a rejection of British colonial values and lifestyle. This seems to suggest that integration with the local people-and the local dogs-is a possible solution to the problem of colonial interaction in Africa. While this is deeply disapproved of in settler society, it seems to be something that Lessing admires.

Through the story of these particular dogs, Lessing raises questions about dogs in general. She suggests that there is a contradiction in people's understanding of dogs. They expect them to be like humans with regard to race and class consciousness but they don't seem to think that a dog could become attached to its mate, or care about its offspring in the way humans do. Even in the wild, the suffering that the dogs undergo is caused by human agency. At one point the older dog, Jock, gets caught in a wire snare and is almost suffocated from the struggle to get loose, but Bill chews through all the strands of wire until he is freed. They return home to the farm with Jock collapsing and wheezing and Bill's teeth worn down from the wire. For his friend he sacrifices his ability to hunt and chew, and thus his means of survival in the wild. After this the dogs continue to hunt and develop a method of teamwork where the animal they are hunting is brought down and held by Bill while Jock comes in to kill the beast and then tears off meat for Bill to eat. Lessing thus suggests that dogs can exhibit so-called human qualities of compassion, loyalty and even self-sacrifice.

The narrator describes a dramatic moment when she finds Bill howling in the bush for his mate who is chained nearby:

He sat and howled his heart out, his muzzle pointed away towards where his mate was chained [...] I couldn't stand it. It made my flesh cold, and I could see the hairs standing up on my forearm. I went over to him and sat by him and put my arm around his neck. [...] But he went on, until suddenly he leaped up in the middle of a howl, as if his pain were too strong to contain sitting, and he sniffed at me, as if to say: "That's you, is it, well, good-bye-then he turned his wild head to the bush and trotted away.

Very soon he was shot, coming out of a chicken-run early one morning with an egg in his mouth. (Lessing, Sun 214)

The interesting thing about this story, as opposed to many narratives featuring dogs, is that the bond between human and dog is not important to the narrator. It is not that the narrator doesn't care about the dogs, but it is not something that features particularly strongly in the narrative. She seems to admire a dog that is 
Wildness and colonialism in "The Story of Two Dogs" by Doris Lessing

aloof from its humans. What is far more important is the bond between dog and dog.

The phenomenon of the human, stepping back in favour of the animal is not because of Othering, or even "Anothering" in Patrick Murphy's terms, but it goes beyond that, as it is respectfully allowing the animal being to have its full expression without curtailment of domestication. This makes one ask whether Lessing's position is then a withdrawal from the process of domestication of dogs altogether? I think that with many of her other stories, she raises questions about human intervention in the nonhuman world, and holds up possibilities, but doesn't prescribe answers. Obviously the very long history of dogs as human companions has a momentum that would never be stopped. However, to pause and re-evaluate the way in which this association affects the life of the dog seems to me one of the major achievements of her story.

In conclusion, this story reveals that dogs have a difficult role to play in a colonial situation as they occupy a space between tameness and wildness and they have to traverse this terrain in relation to conflicting sets of human groups. They are like a prism through which many different aspects of settler society are illuminated and the many-faceted relationship between colonialism and wildness is brought into focus. In particular, the complex relationship between wildness and colonialism is exemplified through representatives of the settler community such as the mother. She has a basically adversarial relationship towards wildness in the dogs. She expects the dogs to behave like humans and in fact like colonialists, exhibiting their same prejudices and keeping to their racially-charged boundaries. In this we see how threatened she is by the wild environment she finds herself in, both in terms of animals and people. This is shown by her emphasis on training.

However, Lessing also establishes an alternative discourse in her story where the human agency is centred in the child or adolescent girl. This focaliser gives the dogs more scope to follow their instincts and to be more true to their wild nature. Through this story, Lessing provides a critique of the conservative colonial concept of "wildness" and offers an alternative which is similar to Gary Snyder's formulation of wildness with regard to animals: "free agents, each with its own endowments, living within natural systems" (10).

Maybe through the dog's narrative she is constructing an alternative narrative to colonialism, although it goes deeper than British colonisation of Africa-it is also about human colonisation of the animal world. She is raising the question of humans interfering in Nature-of making dogs respond to humans in a way that is inappropriate and to deny their "real" natures and instead, finding ways to interact with them in ways that gives them more independence as equal partners. 
Wildness and colonialism in "The Story of Two Dogs" by Doris Lessing

\section{WORKS CITED}

Chennells, A. "Doris Lessing: Rhodesian Novelist." Doris Lessing Newsletter vol. 9, no. 2, 1985, pp. $3-7$.

Fitzpatrick, P. Jock of the Bushveld. Longmans, Green \& Co., 1957.

Haraway, D. J. When Species Meet. U of Minnesota P, 2008.

Hunter, E. "A Sense of Place in Selected African Works by Doris Lessing." Diss. U of Cape Town, 1990.

Kennedy, D. Islands of White. Duke U P, 1987.

Lessing, D. This was the Old Chief's Country: Collected African Stories, Vol. 1. Flamingo, 1994. . The Sun Between Their Feet: Collected African Stories, Vol. 2. Flamingo, 1994. Introduction to The Sun Between Their Feet. Michael Joseph, 1973. Under My Skin. Harper Collins, 1994.

Louw, P. “Wildness' in Doris Lessing's African Stories.” M.A. Thesis. U of Zululand. 2003.

McHugh, S. Dog. Reaktion, 2004.

Mills, S. Discourse. Routledge, 1997.

Murphy, P. "Anotherness and Inhabitation in Recent Multicultural American Literature". Writing the Environment: Ecocriticism and literature. Eds. R. Kerridge \& N. Sammells. Zed, 1998.

Ndlovu-Gatsheni, S. J. "Re-thinking the Colonial Encounter in Zimbabwe in the Early Twentieth Century." Journal of Southern African Studies vol. 33, no. 1. March 2007, pp. 173-91.

Simoes da Silva, Tony. "Narrating a White Africa: Autobiography, race and history." Third World Quarterly vol. 26, no. 3, 2006, pp. 471-8.

Snyder, G. The Practice of the Wild. North Point, 1990.

Stiebel, L. "Imagining Empire's Margins: Land in Rider Haggard's African Romances." Alternation vol. 5, no. 2, 1998, pp. 91-103.

Tropp, J. "Dogs, Poison and the Meaning of Colonial Intervention in the Transkei, S.A." The Journal of African History vol. 43, no. 3, 2002, pp. 451-72.

Watkins, S. Doris Lessing: Contemporary World Writers. Manchester U P, 2015.

Woodward, W. The Animal Gaze: Animal Subjectivities in Southern African Narratives. Wits U P, 2008. 